Jurnal Ilmiah Bimbingan Konseling Undiksha

Volume 12 Number 1, 2021, pp 78-83

ISSN: Print 2598-3199 - Online 2598-3210

Undiksha | DOI: 10.23887/XXXXXX-XX-0000-00

Open Access https://ejournal.undiksha.ac.id/index.php/JIBK/index

\title{
Ingatan II: Pengorganisasian, Lupa dan Model Model Ingatan
}

\author{
Alfun Sandi ${ }^{1^{*}}$ \\ ${ }^{1}$ Magister Bimbingan dan Konseling Universitas Negeri Padang, Sumatera Barat , Indonesia \\ *Corresponding author, e-mail: alfunsandi5996@gmail.com neviyarni.suhaili911@ @mail.com
}

Received January 12th , 2021; Revised Month February 1st, 2021;

Accepted March 15, 2021; Published Online March 20, 2021

\section{Conflict of Interest Disclosures:}

The authors declare that they have no significant competing financial, professional or personal interests that might have influenced the performance or presentation of the work described in this manuscript.

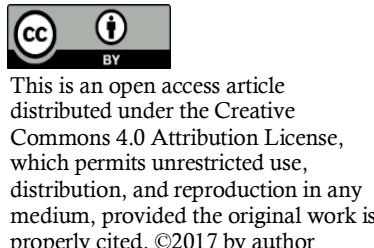

medium, provided the original work
Abstract: Twentieth-century playwright Tennessee William once said that life is memory except for the present moment which passes so quickly that it is hard to remember, so what is memory? Memory or retention is the retention of information over time which involves encoding, storing and retrieving it. Educational psychologists study how information is stored or stored in memory, how it is retained or stored after being encoded, and how it is found or reexpressed for specific purposes at a later date. Memories make us feel sustainable. Without memory, we are unable to relate what happened yesterday to what we are experiencing now. The brain is the most complex device in the world. Trillions of brain cells have specific but related functions. Control all physical and psychological aspects of humans. Either consciously or unconsciously. The memory storage capacity in the brain far exceeds the capacity of even the largest computer hard drive. The brain has the ability to handle an unlimited number of complex algorithms simultaneously, far exceeding the capabilities of even the most advanced computer processors. But unfortunately humans are not able to optimize the full potential of the brain, so the brain does not allow all traces of the memory to be stored perfectly, but will gradually disappear. But when the person concerned is asked to recall things he has already remembered, sometimes some of them start to be forgotten. In this paper, we will discuss things related to memory such as organizing, forgetting, memory models and learning and memory habits.

\section{Keywords: Memory II: Organizing, Forgotten, Memory Models}

Indonesian Abstract: Penulis naskah abad ke-20 Tennessee William pernah mengatakan bahwa hidup adalah ingatan kecuali saat sekarang yang berlalu begitu cepat sehingga sulit untuk diingat, lalu apa itu ingatan? Memori atau retensi adalah penyimpanan informasi dari waktu ke waktu yang melibatkan pengkodean, penyimpanan, dan pengambilannya. Psikolog pendidikan mempelajari bagaimana informasi disimpan atau disimpan dalam memori, bagaimana disimpan atau disimpan setelah dikodekan, dan bagaimana informasi itu ditemukan atau diungkapkan kembali untuk tujuan tertentu di kemudian hari. Kenangan membuat kita merasa berkelanjutan. Tanpa ingatan, kita tidak dapat menghubungkan apa yang terjadi kemarin dengan apa yang kita alami sekarang. Otak adalah perangkat paling kompleks di dunia. Triliunan sel otak memiliki fungsi yang spesifik namun berhubungan. Kontrol semua aspek fisik dan psikologis manusia. Baik disadari maupun tidak. Kapasitas penyimpanan memori di otak jauh melebihi kapasitas hard drive komputer terbesar sekalipun. Otak memiliki kemampuan untuk menangani algoritma kompleks dalam jumlah yang tidak terbatas secara bersamaan, jauh melebihi kemampuan prosesor komputer paling canggih sekalipun. Namun sayangnya manusia tidak mampu mengoptimalkan seluruh potensi otaknya, sehingga otak tidak membiarkan semua jejak ingatan tersebut disimpan dengan sempurna, melainkan lambat laun akan hilang. Tetapi ketika orang yang bersangkutan diminta untuk mengingat hal-hal yang telah dia ingat, terkadang beberapa di antaranya mulai dilupakan. Dalam tulisan ini, kita akan membahas hal-hal yang 
berkaitan dengan memori seperti pengorganisasian, pelupa, model memori dan kebiasaan belajar dan memori.

Kata Kunci: Memori II: Pengorganisasian, Lupa, Model Memori

How to Cite: Alfun Sandi. 2021. Ingatan II: Pengorganisasian, Lupa dan Model Model Ingatan. JIBK Undiksha, 12 (1): pp.78-83. DOI: http://dx.doi.org/10.23887/xxxx

\section{Pendahuluan}

Pada pembahasan kali ini kita membahas bagaimana informasi diorganisasikan dalam memori jangka panjang, dengan penekanan pada peran konteks dalam memori, proses konstruktif, semantic memori, dan pengelompokan persepsi. Contoh lain dari organisasi dalam memori seperti clustering in free recall, organisasi subjektif, dan imagery. Selanjutnya kita memeriksa proses penting dari lupa, berfokus pada pembusukan, gangguan, dan teori informasi pengolahan lupa. Lalu kami sekilas model memori, menekankan model buffer berpengaruh dan model memori manusia asosiatif.

Pendekatan kognitif untuk belajar memberikan peran penting untuk proses organisasi dan menekankan peran aktif dari peserta didik. Pelajar aktif dipandang sebagai pengolahan informasi yang akan dipelajari, bukan hanya pasif mendaftarkan informasi. Pendekatan organisasi untuk belajar dan memori mengasumsikan bahwa kita mencoba untuk mengorganisir informasi kedalam beberapa pola yang bermakna dan merancang strategi, rencana dan merumuskan hipotesis tentang informasi yang dikodekan stored dalam memori. Informasi yang disimpan dalam memori jangka panjang diasumsikan sangat terorganisir untuk memanfaatkan kapasitas penyimpanan yang tersedia dan membantu dalam pencarian dan pengambilan informasi.

Kapasitas penyimpanan memori didalam otak jauh melebihi kapasitas memori terbesar sekalipun. Otak memiliki kemampuan menangani logaritma rumit secara bersamaan dalam jumlah tak terbatas, jauh melebihi kemampuan teknologi canggih sekalipun. Tapi sayangnya manusia tidak mampu mengoptimalkan seluruh potensi otak tersebut, sehingga otak tidak memungkinkan semua jejak ingatan itu tersimpan terus dengan sempurna, melainkan berangsur-angsur angkan menghilang. Tetapi orang yang bersangkutan diminta untuk mengingat kembali hal yang sudah mulai terlupakan sebagian itu.

\section{Hasil dan Pembahasan \\ Pengorganisasian dan Ingatan}

Karakteristik yang penting dalam pembelajaran pada manusia dan ingatannya adalah pengorganisasian. Pendekatan pengorganisasian yang digunakan untuk proses belajar dan proses mengingat digunakan untuk pengorganisasian berbagai informasi menjadi hal-hal yang lebih bermakna. Berikut akan diilustrasikan beberapa proses pengorganisasian, diantaranya adalah:

\section{Konteks dan Ingatan}

Informasi dikodekan dan disimpan dalam memori dapat dengan mudah dipengaruhi oleh kontek di mana informasi tersimpan. Kontek berfungsi untuk membantu mengatur fitur- fitur khusus untuk penempatan dalam memori. Ringkasnya, informasi kontekstual dapat berfungsi mempermudah mengingat informasi yang dikodekan.

Misalnya dalam konteks verbal pada kata "jam" yang kemudian dikodekan menjadi strawberry jam versus traffic jam. Dua kata tersebut akan berbeda dalam proses pengkodean di dalam ingatan. Kegunaan konteks disini adalah melakukan selektif bias berkaitan dengan pengkodean dan penyimpanan.

\section{Proses Konstruktif}

Proses konstruktif merupakan tindakan dimana seseorang dapat mengintegrasikan atau mengorganisasikan informasi ke dalam memori menjadi pola-pola koheren yang disebut sebagai skema. Begitu sebuah skema terbentuk,maka ia akan mempengaruhi cara informasi berintegrasi ke dalam long-term 
memori John Bransford dan Jeffry Franks menunjukkan bahwa manusia mengenal informasi walaupun disajikan secara implicit. Seperti sebuah kalimat yang menunjukkan ide yang kompleks. Contoh: Kucing yang takut dan lari dari anjing yang menggonggong melompat ke atas meja. Kalimat tersebut dapat diuraikan sebagai berikut:

1. Kucing itu takut

2. Kucing itu berlari

3. Anjing itu menggonggong

4. Kucing melompat ke atas meja

\section{Semantic Memory}

Studi tentang memori semantik berhubungan dengan memori alami kita, bahwa memori kita dari kejadian semantik di mana kita memperoleh pengalaman bahasa berbeda dari memori yang kita peroleh dari kejadian dalam laboratorium.

\section{Perceptual Grouping and Memory}

Ide penting dari teori Gestalt tentang memori adalah suatu cara yang dikelompokkan secara perseptual akan menentukan cara tersebut terorganisir dalam memori. Sebagai contoh, nomor telepon dikelompokkan kedalam urutan tiga digit atau empat digit. Umumnya, ide dasar dari pengelompokkan perseptual adalah bahwa stimulus terpisah di lingkungan kita tidak ditanggapi sebagaimana mestinya tetapi diatur perseptual ke dalam beberapa pola terstruktur atau urutan.

\section{Lupa (Forgetting)}

Informasi yang dimasukkan ke dalam long-term memory cenderung bertahan. Namun demikian, informasi pada sistem ini dapat juga terlupa walaupun pada kenyataannya long-term memory merupakan sistem yang lebih stabil dari pada short-term memory. Ada beberapa pendapat tentang pengertian lupa, diantaranya yaitu:

1. Suyanto (1993) Lupa ialah peristiwa tidak dapat memproduksikan tanggapan-tanggapan kita, sedang ingatan kita sehat.

2. Mustaqim (2004) Lupa sebagai suatu gejala di mana informasi yang telah disimpan tidak dapat ditemukan kembali untuk digunakan.

3. Gula dan Reber (dalam Djamarah, 2008) Lupa sebagai ketidakmampuan mengingat atau mengenal sesuatu yang pernah dipelajari sebelumnya.

4. Irwanto (1997) Lupa sebagai hilangnya kemampuan untuk menyebut kembali atau memproduksi Kembali apa- apa yang sebelumnya telah kita pelajari secara sederhana.

Jadi, lupa merupakan kegagalan untuk mereproduksi kembali hal-hal yang sebelumnya telah terjadi yang disebabkan oleh lemahnya item informasi untuk ditimbulkan ulang saat informasi tersebut dibutuhkan.

Masalah prinsip dari memori jangka panjang adalah untuk menentukan penyebab dari lupa setelah waktu lama yang melibatkan praktek tambahan. Pengertian lupa sendiri juga dikemukakan oleh Paul Chance (2009: 345) bahwa "Forgetting is the deterioration of learned behavior after training ends. Forgetting usually involves a decrease in the strength of a behavior, but under certain circumstances, it can mean an increase in strength" sehingga lupa juga dapat dikatakan penurunan perilaku yang dipelajari setelah proses latihan selesai.

Ada beberapa pembahasan berkenaan dengan kelupaan, yaitu:

Teori klasik tentang kelupaan : Decay dan Interference 
Para psikolog memori telah mengusulkan dua jenis teori untuk menjelaskan kelupaan, yakni teori decay dan teori interference. Teori decay beranggapan bahwa jejak memori hipotesis yang merupakan perwakilan dari peristiwa akan berkurang secara otomatis dengan berjalannya waktu.

Sedangkan Teori interference beranggapan bahwa lupa disebabkan oleh pengaruh pembelajaran baru dan pembelajaran sebelumnya.

a. Retroaktif inhibition

Retroaktif inhibition mengacu pada fakta bahwa suatu peristiwa dipelajari selama ingatan interval dapat menyebabkan kelupaan terhadap peristiwa yang telah dipelajari sebelumnya. "In these situations the interferingstimulus acts backward to disrupt the memory of a preceding target event.Therefore, the disruption of memory is called retroactive interference." (Michael Domjan, 2010: 411).

b. Proaktif inhibition

Proaktif inhibition adalah kerugian dalam ingatan yang dihasilkan oleh efek dari beberapa tugas yang dipelajari sebelumnya.

"In these cases the interfering information acts forward to disrupt the memory of a future target event.

Therefore, the disruption of memory is called proactive interference." (Michael Domjan, 2010:411).

c. Faktor yang mempengaruhi retroaktif dan proaktif inhibition

1) Faktor detik yang mempengaruhi ingatan yang dalam paradigma retroaktif inhibition adalah derajat tingkat pembelajaran yang asli yaitu sedang belajar pada tugas awal.

2) Faktor terkait yakni derajat tingkat pembelajaran dari tugas interpolasi

3) Persamaan antara kedua tugas

4) Faktor konstekstual

d. Teori interference

Teori interference dimulai dengan asumsi bahwa kelupaan adalah hasil dari pembelajaran lain yang mencegah proses mengingat kembali sesuatu yang telah dipelajari. Salah satu aspek dari teori interference adalah kompetisi tanggapan.

e. Pendekatan pengolahan informasi tentang kelupaan

Pendekatan pengolahan informasi berpandangan bahwa lupa merupakan hasil dari kegagalan untuk menemubalikkan informasi.

\section{Model-model Ingatan}

Ada dua model memori, yaitu :

\section{Model Buffer}

Model buffer dikembangkan oleh Richard Atkinson dan Richard Shiffrin pada tahun 1968. Model buffer terdiri dari dua komponen dasar yakni : bentuk struktural dan proses kontrol. Bentuk struktural dari model ini terdiri dari sensory register, cerita jangka pendek dan cerita jangka panjang yang merupakan bentuk permanen dari sistem memori. Sedangkan proses kontrol merupakan aspek yang tidak permanen dari sistem memori dan merupakan proses yang sementara di bawah kendali manusia.

\section{Model HAM}

Model HAM dikembangkan oleh John Anderson dan Gordon Bower pada tahun 1973. Model ini menggambarkan memori sebagai sebuah koleksi asosiasi yang saling berhubungan dalam jaringan yang besar. Unit dasar dari model ini disebut proposisi yaitu sebuah hubungan yang bermakna antara unit-unit informasi yang dikodekan dan tersimpan dalam memori.

\section{Kebiasaan Belajar dan Ingatan}

1. Memahami tujuan dari apa yang dipelajari 
Fitur utama dari kebiasaan belajar yang baik adalah bahwa anda memahami tujuan pokok atau tujuan apapun yang anda pelajari. Dalam prakteknya para pada proses pembelajaran terjadi pada memahami sebuah topik yang terdapat pada sebuah buku. Sebelum membaca secara mendalam dan keseluruhan, langkah awal yang dapat dilakukan adalah dengan melakukan review pada konten buku tersebut, dengan demikian maka topik yang akan diperbincangkan tersebut akan semakin jelas.

\section{a. Fokus perhatian pada bahan kajian/studi}

Setelah anda memutuskan untuk mempelajari bab tertentu, fokus perhatian anda pada tugas anda dan menghilangkan rangsangan tidak relevan. Misalnya dalam proses belajar, seorang siswa hendaknya menyingkirkan semua hal yang dapat mengganggu, misalnya mematikan TV, menyingkirkan majalah, dan lain sebagainya. Dalam proses belajar di kelas pun, juga terdapat hal-hal yang tidak relevan dengan ransangan belajar, misalnya melamun pada saat belajar.

\section{b. Menyusun kontingensi penguatan}

Contoh nyata praktek ini adalah melakukan penyusunan jadwal mengenai hal-hal yang akan dilakukan setelah proses belajar selesai. Misalnya akan istirahat dan meminum kopi setelah membaca dua bab suatu buku. Praktek ini menyusun studi anda sehingga anda hadiahi diri anda hanya setelah anda menyelesaikan beberapa tugas atau subgoal yang disebut manajemen diri kontingensi.

\section{c. Mengatur bahan/materi}

Proses pengorganisasian bahan belajar akan lebih mempermudah dalam proses retrieval. Misalnya menyusun suatu konsep dimulai dari hakikat konsep, metodologi konsep, berbagai prinsip yang relevan, beberapa isu berkenaan dengan konsep dan pada akhirnya pada implikasi serta aplikasi dari konsep tersebut. Fitur penting dari kebiasaan belajar yang efisien adalah pengorganisasian materi ke dalam beberapa jenis sistematik dan struktur.

\section{d. Praktek pengulangan}

Hal vital dan terpenting dari ingatan yang efektif adalah dilakukannya praktek langsung dalam proses pengambilan yang menghasilkan informasi.

\section{Simpulan}

Pengorganisasian adalah cara lain untuk melihat proses berlangsungnya pengorganisasian

informasi di dalam memori adalah dengan melihat pengaruh kontek di dalam memori. Bentuk lain dari proses kerja memori adalah constrative process yaitu mengacu kepada tindakan yang dilakukan oleh manusia untuk mampu mengintegrasikan atau mengorganisasikan informasi di dalam memori sehingga informasi tersebut menjadi lebih koheren.

Lupa adalah hilangnya kemampuan untuk mengungkapkan kembali apa-apa yang dipelajari atau yang diketahui sebelumnya. Salah satu penyebab kelupaan adalah kegagalan menggunakan materi yang

dipelajari, dalam arti kata terjadi karena perjalanan waktu, walaupun sebenarnya perjalanan waktu tidak menyebabkan kelupaan, yang menyebabkan kelupaan adalah peristiwa yang terjadi selam perjalanan waktu tersebut. Ada dua teori klasik tentang kelupaan, teori decay dan Teori interference. Teori decay menyimpulkan bahwa alur memori yang merupakan perwakilan dari peristiwa melemah dan berkurang secara otomatis bersamaan dengan perjalanan waktu. Teori interference beranggapan bahwa kelupaan disebabkan oleh pengaruh pembelajaran baru dan pembelajaran sebelumnya.

Model-model memori (models of memory) Ada dua model memori yang sangat penting dalam

kaitannya dengan alur informasi. Pertama adalah model buffer (buffer model) dan yang kedua adalah model memori assosiatif manusia (human associative memory model atau HAM model). Model buffer terdiri dari dua komposisi dasar yaitu bentuk struktural dan proses kontrol. Bentuk struktural merupakan bentuk permanen dari sistem memori, sebaliknya proses kontrol merupakan aspek yang tidak permanen dari sistem memori dan merupakan proses sementara di bawah kendali manusia. Human Associative memory model (model HAM) menjelaskan memori sebagai sebuah koleksi yang saling berhubungan di dalam jaringan yang sangat besar 


\section{Ucapan Terimakasih}

Puji syukur atas kehadirat Allah SWT yang telah memberi nikmat dan karunianya sehingga pemakalah dapat menyelesaikan tugasnya hingga waktu yang telah ditentukan. karena dengan pertolongannyalah karya ilmiah ini dapat tersusun. Salawat beserta salam senantiasa kami sa mpaikan kepada Baginda Rasulullah SAW, ia lah suri tauladan bagi seluruh mahluk di muka bumi ini, maka hanya dengan mengikuti sunnahnya kita berharap akan mendapatkan syafa'at di hari akhir kelak, amin.

Ucapan terima kasih banyak saya sampaikan kepada dosen pembimbing mata kuliah Psikologi Belajar ibu Prof. Dr. Neviyarni S., M.S dengan bimbingan dan arahan mereka maka tugas individu dengan materi Ingatan II: Pengorganisasian, Lupa, dan Model-model Ingatan ini dapat saya selesaikan.

Dalam penyusunan artikel ini tidak luput dari salah, maka dari itu saya mohon koreksinya untuk perbaikan kedepannya, sehingga dapat membuat artikel yang lebih baik lagi.

\section{Refrensi}

Chance, Paul. 2009. Learning and Behavior: Active Learning Edition, Sixth Edition. California: Wadsworth. Djamarah, S. B. 2008. Psikologi Belajar. Jakarta: Rineka Cipta.

Domjan, Michael. 2010. The Principles of Learning and Behavior, 6th Edition. California: Wadsworth. Ellis, Henry C. 1978. Fundamentals of Human Learning. Memory and Cognition.

Irwanto. 1997. Psikologi Umum. Jakarta : Gramedia Pustaka Utama. Mustaqim. 2004. Psikologi Pendidikan. Yogyakarta: Pustaka Pelajar.

Suyanto, A. 1993. Psikologi Umum. Jakarta: Bumi Aksara

Article Information (Supplementary)

\section{Conflict of Interest Disclosures:}

The authors declare that they have no significant competing financial, professional or personal interests that might have influenced the performance or presentation of the work described in this manuscript.

Copyrights Holder: < Alfun Sandi $><2021>$

First Publication Right: JIBK Undiksha

https://doi.org/10.xxxx/ $\mathbf{x x x x x}$

Open Access Article | CC-BY Creative Commons Attribution 4.0 International License.

Word Count:

@creative 